\title{
The Semarang City Policies on Complaints Handling During the Covid-19
}

\author{
Suwandi \\ \{ suwandi@lecturer.undip.ac.id \} \\ Vocational School of Diponegoro University, vokasi@live.undip.ac.id
}

\begin{abstract}
The research has aimed at describing Semarang City policies on complaints handling during the Covid-19. The method was a qualitative descriptive approach. Desk review and in-depth interview technique applied to collect data while an interactive model was used to analyze it. The result showed that the complaints handling is under the Complaints Handling Management Center (P3M). Lapor Hendi, a one-stop complainthandling platform set up by the Semarang government to manage complaints. The call center 112 in the emergency used to receive the complaints. We found that the Standard Operational Procedure (SOP) of LaporHendi does not accommodate the Covid-19 situation based on the Minister Regulation SE MenpanRB Number 53 of 2020. Also, the complaints collected by the government were only for the evaluation material.
\end{abstract}

Keywords: Complaints, Semarang, Covid-19

\section{Introduction}

The Covid-19 put the world into crisis in Indonesia. In this situation, the government expected to handle the situation especially dealing with social and economics. On the other hand, the government provides some regulations to reduce social and economic impacts. They relocated as well as refocused the 2020 budget. The local government made adjustments to the 2020 APBD according to the Joint Decree of the Minister of Home Affairs and Minister of Finance Number 119/2813/SJ and 117/KMK.07/2020 about the Acceleration of the 2020 APBD Adjustment for handling the Covid-19.

Semarang City Government has reallocated about 189 billion rupiahs from the APBD for buying medical devices in the form of masks and hand sanitizers, providing disinfectant spray, making social networks, and giving social assistance for people affected by the Covid-19. [9] The government has distributed social assistance package to people affected the Covid-19.[9] by a total of 445,480 . [10]

The budget on social assistance (BANSOS), the procurement of goods and services related to Covid-19 are vulnerable to corruption. It concluded from the number of complaints submitted to the government. Based on the OMBUDSMAN of the Republic of Indonesia representing Central Java, the complaints received mostly related to the social assistance distribution. [3], [11]

Either local or center government should provide management of handling-complaints as the obligation mandated by law number 25 of 2009 concerning public services. The accessibility of public complaints must be taken seriously anytime and in any situation. Therefore, it is 
interesting to look at how Semarang City governments manage complaints related to social assistance during the Covid-19.

\subsection{Theoretical Review}

Based on Islamy, complaints or service complaints are dissatisfaction expressions with service, actions, or inaction to public officers that affect the customers [2]. According to Syukri (2009) [3], complaints are significant sources of information to correct errors. Besides, the complaints can consistently maintain and improve services to be predetermined standards.

Complaint Handlings are activities of receiving the complaints, processing responses, feedback, and complaints handling reports. These series of activities consist of: (1) Source of the Complaint; the citizens, individual and in groups, and where the complaint comes from, (2) Content of the Complaint; the problem complained by the public, (3) Complaint Handling Unit; Unit provided by the institution to manage and handle complaints, (4) Complaint responds; responses produced by the complaint handling unit in the government institution related, (5) feedback; the assessment on the complaints responses of each institution and (6) Complaint Handling Report; a report and response from the public or the institutions. [1]

\section{Methodology}

\subsection{Research Types}

This study applied the qualitative descriptive approach. It described the complaint handling in the Semarang City during the Covid-19. The researcher conducted library research by reviewing several documents related to complaining management social assistance. The indepth interview was held with officers from the Semarang City Department of Communication, Informatics, Statistics, and Encryption to obtain further information.

\subsection{Research Setting}

The research was conducted from March to July 2020 in Semarang City, Central Java.

\subsection{Research Subject}

The subject is the Department of Communication, Informatics, Statistics, and Encryption of Semarang City.

\subsection{Data collection}

The data collection technique was a desk review by reviewing several documents related to the complaint handling problem in Semarang City during the Covid-19. The depth-interview has finished getting more data.

\subsection{Data analysis}

This study used an interactive model to analyze the data focusing on data reduction, data presentation, conclusions, and verification.

\section{Finding And Discussion}

The Complaint management in Semarang City run based on the Mayor Regulation Number 34 of 2017 concerning Guidelines for Managing Public Complaints about Public Services. The regulation stated that the government forms a team complaints management via the LaporHendi platform integrated with SP4N-Lapor! 


\subsection{Public Complaints Profile of Semarang City during the Covid-19}

From April to May 2020, the number of complaints received through SP4N-Lapor! and the LaporHendi were 587 reports. The highest number of complaints received through the SP4N-Report! is social assistance of $56 \%$ of the 82 as shown in the following figure:

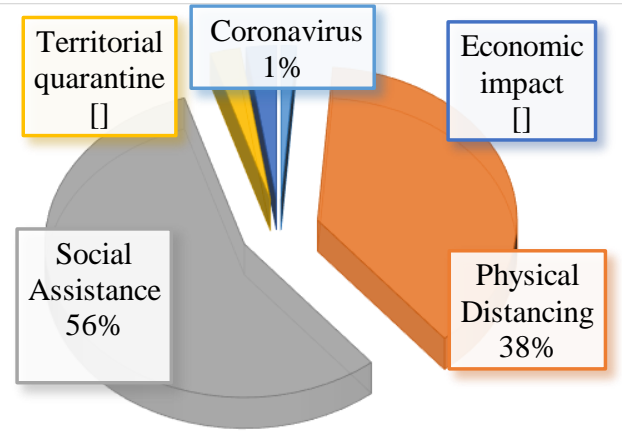

Fig. 1. The topic of complaints received through SP4N-Lapor!

The most complained topic via LaporHendi was cash assistance of 38\% of 241 reports.[6] As shown in the following figure:

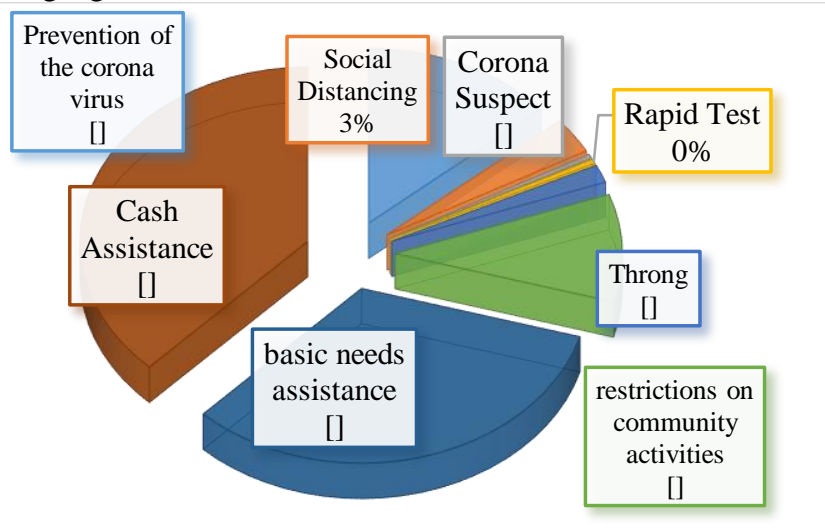

Fig. 2. The topic of complaints received through LaporHendi

The complaints follow-up process on the Covid-19 social assistance maximum of 2 days after it is received. The result showed that the number of complaints via SP4N-Lapor! and LaporHendi were 323 reports in May 2020. 65.3\% of them have already followed up. 31.6\% are still in the follow-up process, and $3.1 \%$ have not been following up.[6] 


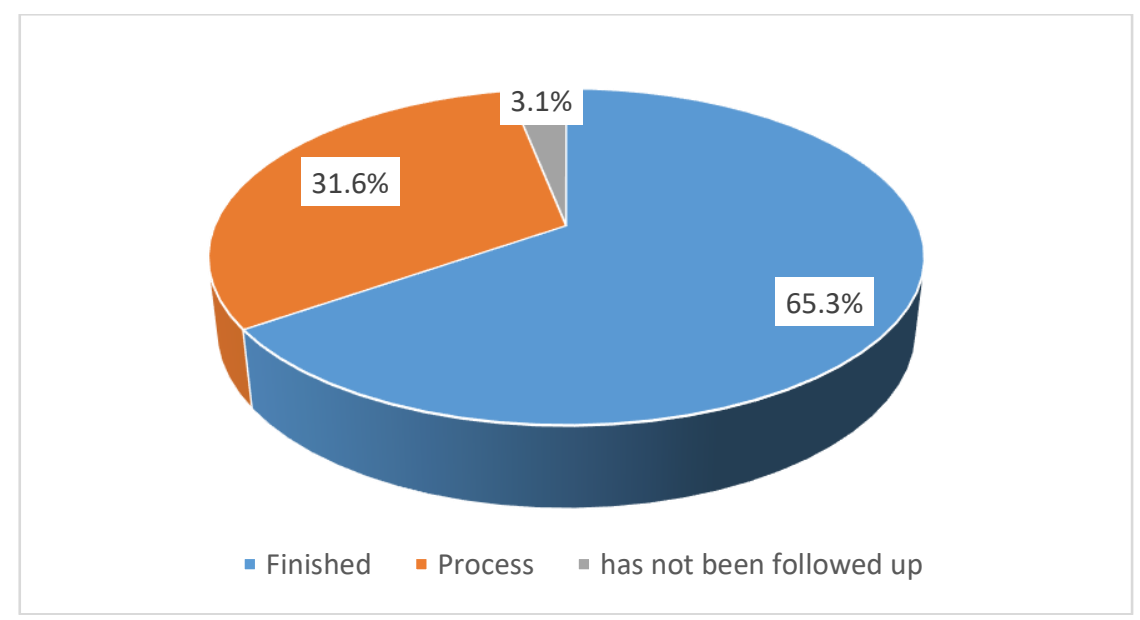

Fig. 3. Follow-up complaints about the May 2020 period

3.2 Regulatory Aspects of Complaint Handling in the Semarang City During the Covid-19

In the Covid-19 situation, the Minister of Administrative and Bureaucratic Reform (PANRB) issued a regulation of the Minister of PANRB Number 53 of 2020 regarding Special Mechanisms in the national public service complaint management system (SP4N-Report!) to support the handling of the impact of Covid-19 in Government. This regulation is a guideline for following up complaints on public services via SP4N-Report! Application. It is also the basis for the Semarang City government in managing complaints related to the impact of the Covid19.

The objectives of this Letters are:

1. To accelerate the follow-up to resolve complaints about the impact of Covid-19 through SP4N-Lapor!

2. To ensure the implementation of the duties and functions of each government institution run effectively achieving good performance on complaint management in each organization;

3. Ensure public services run effectively. Related to the complaint resolution mechanisms, they are to the Regulation of the Minister of PANRB Number 62 of 2018 concerning guidelines for the national public service complaint system.

The letter put the complaint handling related to the Covid-19 impact as the prioritize namely the special category. Its Health, social and economic issues submitted using the SP4NLabor. The speed of complaint handling during the Covid-19 is regulated well. The complaint handling process from the admin to the complaint management team must be done a maximum of 1 (one) day after received. The complaint regarding the impact of Covid-19 is a maximum of 2 (two) office days must be follow up after received by the team.

The results showed that the Semarang City Government did not have a derivative legal regulation of the letter. They did not adjust the LaporHendi complaint service SOP as the mandate of the letter. Unfortunately, the SOP states that the time needed from the complaint to the responses from the OPD / BUMD 5 days. Therefore, it concluded that the current SOP not fulfilled the emergency aspect of complaints handling during the Covid-19. 


\subsection{Institution and Public Complaint Facilities during the Covid-19}

Based on the Semarang Mayor Regulation Number 11 of 2017 concerning the center for community complaint management, the institution that assists the Mayor in coordinating, clarifying, and managing public complaint is the Complaint Management Center (P3M)[7]. It is in the Department of Communication, Informatics, Statistics, and Encryption.

We found that the complaint management institution during the Covid-19 normal situation has no difference in general. The complaint management team in Semarang City consists of the Mayor and the Vice Mayor the supervisors, the Regional Secretary as the person in charge, the Head of the Department of Communication, Informatics, Statistics and Encryption as the Chair, and the head deputy of Information Management and Public Communication Channels at the Department of Communication, Informatics, Statistics, and Encryption as the vice [5]. The secretary is the Head Deputy of the Aspiration and Information Management at the Department of Communication, Informatics, Statistics, and Encryption. The members, admin, and Liaison Officer of the LaporHendi platform are regional apparatus organization in Semarang City.[6]

The P3M team's responsibilities are managing complaints that will be followed up at the national level by the SP4N-Report, forwarding the complaint to the OPD and/ BUMD administrators, (3) monitoring the complaint follow-up and resolution within the OPD and/ BUMD, and (4) evaluating the complaint management regularly every three months. The evaluation includes the number of complaints, OPD and/ BUMD complaints resolved or not, and the follow-up complaint information to the national complaint management(SP4N-Report!). It will return if it is not under its authority.[8]

Meanwhile, the main complaint facilities provided by the Semarang City government for the provision of covid-19 social assistance via the LaporHendi integrated with the SP4N-Report! Application. The complaint service is via WhatsApp at number 081215000512, Telegram at Semarang City Government account, Instagram account @ hendrarprihadi, Twitter \#LaporHendi, and SMS to 1708 with the format LaporHendi (space) complaint. The government also provides the offline complaint facility, the Public Complaint Management Center (P3M) office Semarang city.

The emergency complaints that require immediate handling, the public can contact the 112 call center. They can report the complaints related to social assistance to the call center. Besides, there is also an ambulance service to telephone numbers 1500-132 and counter services for doctor consultation via WhatsApp number 08112900132 that open 24 hours.

\subsection{Transparency and Accountability of Public Complaints during the Covid-19}

Socialization of the LaporHendi complaint facility and 112 call center carried out online and offline. The online media are Instagram of the Mayor of Semarang, P3M and Semarang City Government, Twitter, and Facebook. On the other hand, the offline socialization done via billboards, Videotron, BRT buses, public service counters, Car Free Day (CFD), goes to campus activity and goes to village activity. During the Covid-19, socialization was mostly by online media.

Semarang Mayor Regulation Number 34 of 2017 concerning guidelines for managing public complaints regarding public services states that complaint management reports published to the public as a form of transparency and accountability.[8] However, we found that the government has not published yet, but they only submitted them to the Mayor as evaluation material. Complaints reports are collected each month during the covid-19. The Semarang City government gave the complaints reports to the Ministry of PANRB. They used for evaluating the types, the number, and the follow-up it. 
The good news is the Semarang City government is creating an application that allows complaints to be monitored online in real-time by the public via semarsatata.semarangkota.go.id portal now.

\section{Conclusion}

We can conclude that the Semarang City did not have derivative legal regulations as a follow-up to the issuance of the Minister of PANRB Number 53 of 2020 about Special Mechanisms in the national public service handling-complaint management system (SP4N) [4]. On the other hand, the Standard Operational Procedure (SOP) of the LaporHendi has not yet fulfilled the emergency aspect of complaints handling during the Covid-19. On the other hand, the Mayor helped by the Complaint Handling Management Center (P3M) to coordinate, clarify, and manage public complaints like normal conditions. Given transparency, the government has not published a handling complaints report to the public but just submitted it to the Mayor for evaluation.

Suggestions

1. The Semarang City Mayor should instruct the Department of Communication, Informatics, Statistics, and Encryption of Semarang City to arrange complaint handling Standard Operational Procedure (SOP) for the pandemic situation. The process of the arrangement has to involve the community that focused on the handling complaints issue.

2. The Department of Communication, Informatics, Statistics, and Encryption of Semarang City needs to provide an application/portal that allows complaints to be monitored online and in realtime by tmhe public as soon as possible for transparency and accountability in handling complaints.

\section{References}

[1] Bappenas, Laporan Kajian, Manajemen Pengaduan Masyarakat dalam Pelayanan Publik. Direktorat Aparatur Negara. Jakarta. Bappenas, 2010.

[2] Saleh, A. Muwafik . Public Service: Communication. Malang: UMM press, 2010.

[3] Syukri, Agus Fanar. Standar Pelayanan Publik Pemda (Berdasarkan ISO 9001/IWA-4). Bantul: Kreasi Kencana, 2009

[4] Circular letter of the Minister of PANRB Number 53 of 2020 regarding Special Mechanisms in the national public service complaint management system (SP4N) Report! In order to support the handling of the impact of Covid-19 in Government Agencies.

[5] Decree of the Head of Department of Communication, Informatics, Statistics and Encryption of Semarang City Number 067/20/2017 concerning standard operating procedures in the field of service within the Department of Communication, Informatics, Statistics and Encryption of Semarang City.

[6] Decree of the Mayor of Semarang Number 481.4 / 24 of 2019 concerning the formation of a complaint management team for LaporHendi.

[7] Regulation of Semarang Mayor Number 11 Year 2017 Concerning the Semarang City Public Complaint Management Center.

[8] Regulation of Semarang Mayor Number 34 of 2017 concerning Guidelines for Managing Public Complaints About Public Services. 
[9] Derapjuang.id "Pemerintah kota Semarang relokasi anggaran 189 miliar untuk penanganan pandemi covid-19" Mei $1^{\text {st }} 2020$. (accessed on June $24^{\text {th }} 2020$ ) https://derapjuang.id/featured/pemerintah-kota-semarang-realokasi-anggaran-189miliar-untuk-penanganan-pandemi-covid-19/.

[10] Infobansos.semarangkota.go.id. 'Informasi data bantuan sosial (covid) semarang' June $7^{\text {th }} 2020$. (accessed on June $7^{\text {th }}$ 2020)http://infobansos.semarangkota.go.id/.

[11] Ombudsman.go.id "Posko Pengaduan Daring Ombudsman Jateng Banjir Laporan” Mei $5^{\text {th }}$ 2020. (accessed on June $24^{\text {th }} 2020$ ) https://ombudsman.go.id/artikel/r/artikel--poskopengaduan-daring-ombudsman-jateng-banjir-laporan. 